\title{
Clinically Visible Congenital Birth Defects, Case of the Kenya Health District in the Democratic Republic of the Congo
}

\author{
Nama Mwengu Cecile1, Mizelo waKumwimba², Ngoy Shindano Romain ${ }^{3}$, \\ Iungamakonga Dressen ${ }^{4}$, Lunkutu kitambala Hugues ${ }^{5}$, Kimbamukanya Pascal ${ }^{6}$, \\ Matungulu Matungulu Charles ${ }^{1}$, Ilunga Kandolo Simon ${ }^{1 *}$, Mundongo Tshamba Henry ${ }^{1}$, \\ Kabyla Ilunga Benjamin 1,6, Malonga Kaj Francoise ${ }^{1,6}$

\footnotetext{
${ }^{1}$ School of Public Health, University of Lubumbashi, Lubumbashi, The Democratic Republic of Congo

${ }^{2}$ High Medical Technical School of Manono, The Democratic Republic of Congo

${ }^{3}$ High Medical Technical School of Lubumbashi, The Democratic Republic of Congo

${ }^{4}$ High Medical Technical School of Kamina, The Democratic Republic of Congo

${ }^{5}$ School of Medicine, University of Likasi, Likasi, The Democratic Republic of Congo

${ }^{6}$ School of Medicine, University of Lubumbashi, Lubumbashi, The Democratic Republic of Congo

Email: *silungak@gmail.com
}

How to cite this paper: Cecile, N.M., waKumwimba, M., Romain, N.S., Dressen, I., Hugues, L.K., Pascal, K., Charles, M.M., Simon, I.K., Henry, M.T., Benjamin, K.I. and Francoise, M.K. (2019) Clinically Visible Congenital Birth Defects, Case of the Kenya Health District in the Democratic Republic of the Congo. Open Access Library Journal, 6: e5440.

https://doi.org/10.4236/oalib.1105440

Received: May 5, 2019

Accepted: May 24, 2019

Published: May 27, 2019

Copyright $\odot 2019$ by author(s) and Open Access Library Inc.

This work is licensed under the Creative Commons Attribution International License (CC BY 4.0).

http://creativecommons.org/licenses/by/4.0/

(c) (i) Open Access

\begin{abstract}
INTRODUCTION: Congenital birth defects are real, and they can affect any woman carrying a pregnancy. A particular action must be carried out for preventive purposes. METHODOLOGY: We carried out a cross-sectional study on congenital birth defects in the health district of Kenya. Our study included 68 children born with congenital malformation. This study concerned the six health facilities in the Kenya Health Zone that have maternity clinics from 2010 to 2014. The results were analyzed on SPSS version 23. RESULTS: Of the 68 children born with congenital malformation recorded during our study period, 54\% were female compared to 46 males. There is no statistically significant relationship between congenital birth defects and antenatal care as shown in Table 1 (OR: 1.2, P-value equals 0.79). There were more cases of congenital malformation in 2014 74\% followed by 2013 with 59\%. The year 2010 recorded 5 cases or $13 \%$. CONCLUSION: Congenital birth defects are a health problem in the world. They spare no corner around the world. The Democratic Republic of the Congo and especially the Sanitary District of Kenya are also concerned. It is expected that primary prevention measures will be strengthened because today's children are the future of tomorrow.
\end{abstract}

\section{Subject Areas}

Public Health 


\section{Keywords}

Birth Defects, Congenital, Kenya, Lubumbashi

\section{Introduction}

According to Traoré quoted by Alassane [1], the child occupies a very important place in the family and its role in the family balance is decisive. The care of a child with a congenital malformation is difficult for parents, society and healthy social services. A woman who gives birth to a malformed child is often the subject of harsh and guilty accusations by African society. Congenital birth defects are an important cause of mortality until Age 40. They originate from a stop in the formation and construction of an organ or tissue. They are responsible for: $25 \%$ to $30 \%$ of perinatal mortality; $25 \%$ of infant mortality and around $20 \%$ of handicaps of all kinds. Its frequency in the population is a function of age, regions and countries.

A malformation (dysgenesis, primary malformation) is an irreversible abnormality of the conformation of a tissue, an organ or a larger part of the body, resulting from an intrinsic developmental disorder.

Malformations are often described as congenital or constitutional because they are present at birth. This repetition consecrated by the use is useless, any malformation being by definition congenital, whether it is observed at birth or later. Indeed, true (or primary) malformations are contrasted with deformities and disruptions that are secondary to an extrinsic factor (secondary malformations). This distinction is important because of its implications for genetic counseling [2].

Congenital disorders are common. According to WHO estimates, congenital anomalies in 2004 caused some 260,000 deaths worldwide (about 7\% of all neonatal deaths). They become the most important cause of mortality when the overall mortality rate is low, for example in the European Region, where up to $25 \%$ of neonatal deaths are attributed to congenital anomalies [3].

The term congenital anomalies are used to describe congenital anomalies, abnormalities or dysfunctions present at birth [1].

According to the WHO cited by Liu Shilang [4], congenital abnormalities may be structural (such as structural health defects) or functional (such as metabolic disorders). Abnormalities may be present at conception, but mainly during the embryonic period (from conception to the end of the seventh week of gestation) or from the beginning of the fetal period (from the eighth to the sixteenth week of gestation). It should be noted that some congenital anomalies may not be diagnosed until months or years after birth.

In Canada, about one in 25 babies is diagnosed with one or more birth defects each year [4]. 


\section{Methodology}

We conducted a cross-sectional study of congenital birth defects at the six health facilities in the Kenya Health Zone that have functional maternity clinics from 2010 to 2014

The study population is made up of all the children born malformed during this period, and their mothers from whom we have also taken some elements to enrich more and more our work.

We included in our study any child born in the six health facilities in the Kenya Health Zone with a visible abnormality from birth.

Any child born outside the health study area was not included in this study.

Our data were collected on the basis of a card containing various epidemiological parameters.

The collected data were encoded in Excel and analyzed by SPSS software version 23.

\section{Discussion}

Among the 68 children with congenital malformation recorded during our study period, $54 \%$ were female versus 46 males, as shown by Figure 1 . Our results are similar to those found by RUHANGA on a sample of 52 neonates who presented only one or more external malformations visible at birth to the neonatology unit of the North Kivu provincial hospital and that from January 1, 2011 to December 31, 2016 where the female predominates over the male sex with 53.8\% [5]. In the pediatric department of the SuroSanou University Hospital in Mali, out of 39 cases $(59.1 \%)$ of females compared to 27 cases (40.9\%) of males [6]. These results are different from those found by AlassaneSanogo who found a predominance of the male sex with $56.1 \%$ versus $43.9 \%$ [1].

The months of September and December recorded more cases of congenital birth defects in our series (Figure 2).

There is no statistically significant relationship between congenital birth defects and antenatal care as shown in Table $1(\mathrm{OR}: 1.2$, P-value $=0.79)$. However, according to Sangara, Tiembe and Hamdani [7] [8] [9], quoted by Ruhanga [5], the organization of good prenatal refocused consultations and effective supplementation with folic acid are simple but effective prophylactic measures of definite prevention. congenital birth defects known as those of the neural tube and any other neonatal morbidity. Some authors cited by Ruhanga, this last prophylactic measure has been successfully applied in several Western countries, Asia and America such as Ireland, China and USA.

There is a significant relationship between the type of delivery and the occurrence of death in a child with a congenital malformation: OR 6.3; P-value equals 0.0005 (Table 2). Children born of a dystocic birth have a 6.3 probability of dying than those born from a eutocic birth. This result differs from that found in Mali, where the majorities (93.9\%) of the malformed children came from eutocic pregnancies [1]. The death rate is $6.3 \%$, which is different from that found by 
Ekane (33\%) in Cameroon (Halle-ekane 2016).

The age of pregnancy influences statistically polydactyly. Pregnancy age less than or equal to thirty-six weeks is not a predictor of polydactyly, OR: 4.3 [1.01 16.9]; P-value: 0.031 (As shown in Table 3).

Table 4 shows that multiple malformations are not associated with P-Value pregnancy age $=0.007$.

In our series, we recorded more cases of congenital malformation in 2014 that is $74 \%$ followed by the year 2013 with $59 \%$. The year 2010 recorded 5 cases or 13\% (Table 5).

Figure 3 indicates that among the malformations encountered in the Lubumbashi health district of Kenya, multiple malformations were in first position with (254\%) followed by polydactyly (20\%), bookbill, clubfoot, and hydrocephalus (12\%), the cleft lip (8\%) while the spinabifida, macrocephaly and baby cyamies have $4 \%$ each.

Our results are contrary to those found by Ruhanga who observed that digestive malformations were in the majority with Omphalocele (26.9\%) (Ruhanga 2018). In Cameroon, polydactilia was the most frequently encountered malformation $(24.7 \%)$ [10].

Table 1. Distribution of malformed children and antenatal care.

\begin{tabular}{cccccccc}
\hline & \multicolumn{2}{c}{ Death } & & & & \\
Antenatal \\
\cline { 2 - 4 } Care & Yes N (\%) & Total & OR & CI $_{95 \%}$ & Chi square & P-value \\
\cline { 2 - 5 } No & $5(41.7)$ & $7(58.3)$ & 12 & 1.2 & {$[0.3-4.2]$} & 0.073 & 0.79 \\
Yes & $21(37.5)$ & $35(62.5)$ & 56 & 1 & & & \\
\hline
\end{tabular}

Table 2. Distribution of congenital birth defects and the vital prognosis according to the type Birthing.

\begin{tabular}{|c|c|c|c|c|c|c|c|}
\hline \multirow{3}{*}{$\begin{array}{l}\text { Dystocic } \\
\text { childbirth }\end{array}$} & \multicolumn{2}{|c|}{ Death } & \multirow{3}{*}{ Total } & \multirow{3}{*}{ OR } & \multirow{3}{*}{$\mathrm{CI}_{95 \%}$} & \multirow{3}{*}{ Chi square } & \multirow{3}{*}{ P-value } \\
\hline & & No & & & & & \\
\hline & & $\mathrm{N}(\%)$ & & & & & \\
\hline Yes & $18(62.1)$ & $11(37.9)$ & 29 & 6.3 & [2.2 - 18.7] & 12.2 & 0.0005 \\
\hline No & $8(20.5)$ & $31(79.5)$ & 39 & 1 & & & \\
\hline
\end{tabular}

Table 3. Distribution of congenital birth defects (polydactilia) with the age of pregnancy.

\begin{tabular}{|c|c|c|c|c|c|c|c|}
\hline \multirow{3}{*}{$\begin{array}{c}\text { Age of } \\
\text { Pregnancy }\end{array}$} & \multicolumn{2}{|c|}{ Polydactylia } & \multirow{3}{*}{ Total } & \multirow{3}{*}{ OR } & \multirow{3}{*}{$\mathrm{CI}_{95 \%}$} & \multirow{3}{*}{ Chi square } & \multirow{3}{*}{ P-value } \\
\hline & & No & & & & & \\
\hline & & $\mathrm{N}(\%)$ & & & & & \\
\hline$\leq 36$ & $11(30.6)$ & $25(69.4)$ & 36 & 4.3 & [1.01 - 16.9] & 4.6 & 0.031 \\
\hline $37+$ & $3(9.4)$ & $29(90.6)$ & 32 & 1 & & & \\
\hline
\end{tabular}


Table 4. Distribution of multiples congenital birth defects comparing tothe pregnancy age.

\begin{tabular}{|c|c|c|c|c|c|c|c|}
\hline \multirow{3}{*}{$\begin{array}{l}\text { Age of } \\
\text { pregnancy }\end{array}$} & \multicolumn{2}{|c|}{$\begin{array}{c}\text { Multiples } \\
\text { congenital birth defects }\end{array}$} & \multirow{3}{*}{ Total } & \multirow{3}{*}{ OR } & \multirow{3}{*}{$\mathrm{CI}_{95 \%}$} & \multirow{3}{*}{ Chi square } & \multirow{3}{*}{$P$-value } \\
\hline & \multirow{2}{*}{ Yes N (\%) } & No & & & & & \\
\hline & & N (\%) & & & & & \\
\hline$\leq 36$ & $1(2.8)$ & $35(97.2)$ & 36 & 0.1 & [1.01-0.73] & 7.3 & 0.007 \\
\hline $37+$ & $8(25)$ & $24(75.5)$ & 32 & 1 & & & \\
\hline
\end{tabular}

Table 5. Distribution of congenital birth defects by years of onset.

\begin{tabular}{cccc}
\hline Year & Congenital birth defects & Birth & Prevalence \\
\hline 2010 & 5 & 3324 & 0.13 \\
2011 & 10 & 3391 & 0.29 \\
2012 & 9 & 2752 & 0.33 \\
2013 & 16 & 2722 & 0.59 \\
2014 & 28 & 3782 & 0.74 \\
TOTAL & & & \\
\hline
\end{tabular}

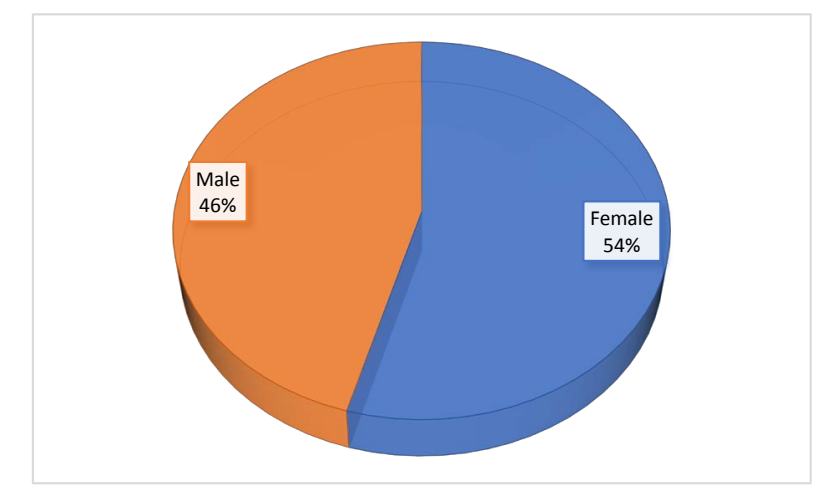

Figure 1. Sexe des enfants avec malformation congénitale.

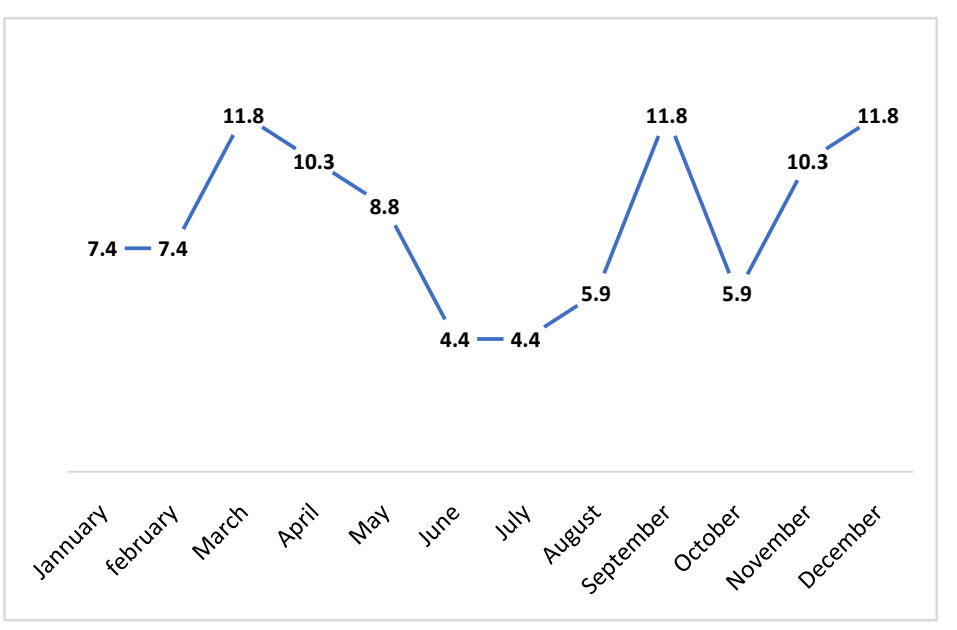

Figure 2. Congenital birth defects by month. 


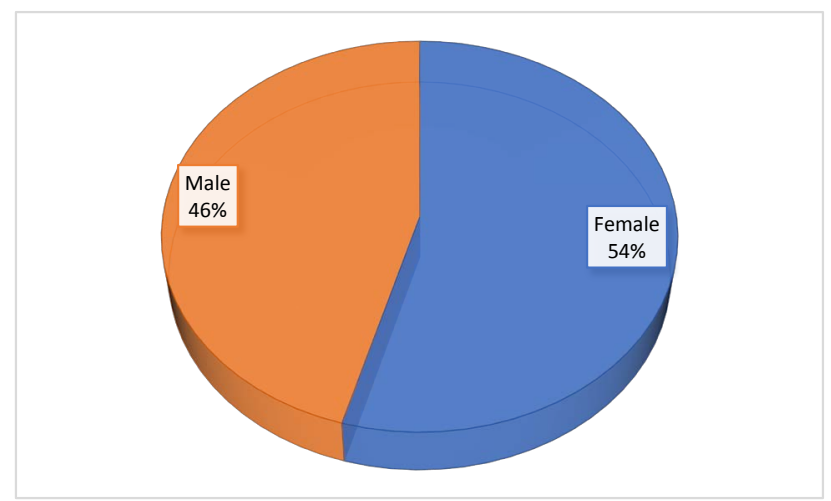

Figure 3. Kinds of congenital defects.

\section{Conclusions}

Multiple malformations were in first position with (254\%) followed by polydactyly (20\%). Multiple malformations are not associated with P-Value pregnancy (age $=0.007)$. Children born of a dystocic birth have a 6.3 probability of dying than those born from a eutocic birth.

There is an urgent need for policymakers to draw attention to measures aimed at early detection of congenital birth defects with a focus on health education using traditional health education channels.

\section{Conflicts of Interest}

The authors declare no conflicts of interest regarding the publication of this paper.

\section{References}

[1] Alassane, S. (2006) Etude des mal formations congénitales dans le service de pédiatrie de l'hôpital Gabriel Touré á propos de 98 cas.

[2] CoPath (2012) Pathologie du développement: Malformations congénitales.

[3] OMS (2010) Malformations congénitales.

[4] Liu, S., Joseph, K.S., Luo, W., León, J.A., Lisonkova, S., Van Den Hof, M., Evans, J., Lim, K., Little, J., Sauve, R. and Kramer, M.S. (2016) Effect of Folic Acid Food Fortification in Canada on Congenital Heart Disease Subtypes. Circulation, 134, 647-655. https://doi.org/10.1161/CIRCULATIONAHA.116.022126

[5] Ruhanga, M. (2018) Les malformations congénitales a 1 est de la république démocratique du congo: Defis et perspectives les malformations congénitales a l 'est de la république démocratique du congo: Defis et perspectives. Int. j. innov. sci. res., 33, 256-261.

[6] Youl, H. (2011) Malformations congénitales reconnaissables à la naissance chez les nouveau-nés dans le département de pédiatrie du centre hospitalier universitaire souro sanou.

[7] Hamdani, E. (2013) Soins prénatals dans la ville de Marrakech. Med et Santee Trop. Santé Trop.

[8] Sangare (2010) Consultation prénatale recentrée: Connaissances, attitudes et pratique de la communauté de Senou. Université de Bamak. 
[9] Tiembre (2010) Evolution de la qualité des CPN dans les districts sanitaires de Grand Bassan (Cote d'Ivoire). Santé Publique, 2, 221-228. https://doi.org/10.3917/spub.102.0221

[10] Halle-ekane, G.E. (2016) Les malformations congénitales à 1 'Hôpital Général de Douala: Aspects épidémiologiques et cliniques. J. la $S A G O, 14,16$. 